\title{
Regulation of Appetite, Satiation, and Body Weight by Enteroendocrine Cells. Part 2: Therapeutic Potential of Enteroendocrine Cells in the Treatment of Obesity
}

\author{
Carsten Posovszky ${ }^{\mathrm{a}}$ Martin Wabitsch ${ }^{\mathrm{b}}$ \\ a University Outpatient Clinic for Pediatric Gastroenterology and b Division of Pediatric Endocrinology and Diabetes, \\ Department of Pediatrics and Adolescent Medicine, University Medical Center Ulm, Ulm, Germany
}

\begin{abstract}
Key Words
Enteroendocrine cells $\cdot$ Satiation $\cdot$ Appetite $\cdot$ Obesity $\cdot$ Taste receptors
\end{abstract}

\begin{abstract}
Obesity is an epidemic and medical issue. Investigating the pathways regulating appetite, food intake, and body weight is crucial to find strategies for the prevention and treatment of obesity. In the context of therapeutic strategies, we focus here on the potential of enteroendocrine cells (EECs) and their secreted hormones in the regulation of body weight. We review the role of the enteroendocrine system during weight loss after lifestyle intervention or after bariatric surgery. We discuss the therapeutic potential of EECs and their hormones as targets for new treatment strategies. In fact, targeting nutrient receptors of EECs with a nutritional approach, pharmaceutical agents or prebiotics delivered to the lumen may provide a promising new approach.
\end{abstract}

(c) 2015 S. Karger AG, Basel

\section{Introduction}

The current worldwide obesity epidemic is a growing medical issue. In fact, overweight and obesity are the fifth leading risk for global deaths as stated in the WHO fact sheet No. 311. Importantly, even a moderate weight loss has a significant health benefit. Dietary lifestyle interventions reducing energy intake effectively reduce weight but do not work well in the long term [1]. If lifestyle interventions fail to control body weight, we need other effective and safe treatments. To date, only bariatric surgery is efficient for long-term weight reduction and reduces overall mortality in severely obese patients [2]. The convincing effect of these surgical interventions is not only due to limiting food ingestion or malabsorption but also due to altered gut hormone release [e.g. peptide YY (PYY), glucagon-like peptide 1 (GLP-1), and ghrelin] [3] affecting appetite and satiety. Pharmacological approaches using gut hormones are often disappointing as these hormones have a short half-life in the blood (e.g. GLP-1) and adverse effects. Therefore, investigating gut hormone-producing enteroendocrine cells (EECs) as targets for weight management seems to be reasonable.

Targeting EEC nutrient receptors and thereby inducing the release of their hormones, e.g. GLP-1 via GPR119, is possible and might be an alternative treatment option also in humans [4]. In fact, nutrition alters the differentiation of EECs and, thus, the gut hormone profile, e.g. L-cell differentiation and the release of GLP-1 are promoted by non-digestible carbohydrates [5]. Finally, the microbiome and its products directly influence differentiation and function of EECs $[6,7]$. On these grounds,

\section{KARGER 125}

() 2015 S. Karger AG, Base

$1663-2818 / 15 / 0831-0011 \$ 39.50 / 0$

E-Mail karger@karger.com

www.karger.com/hrp 
prebiotics may have beneficial therapeutic properties in the treatment of obesity [8]. Here, we review the therapeutic potential of EECs in the treatment of obesity.

\section{EECs in the Context of Therapeutic Approaches towards Body Weight Control}

Energy homeostasis, satiety and body weight are centrally regulated in a highly complex system comprising orexigenic centres with neurons expressing NPY and AgRP or anorexigenic centres with proopiomelanocortin (POMC) as well as cocaine and amphetamine-regulated transcript (CART)-expressing neurons in the hypothalamus. Peripheral regulators comprise hormones derived from the gastrointestinal (GI) tract, the pancreas, and the adipose tissue [9]. The gut-brain axis involves both neuronal and hormonal signals that are generated in the GI tract (fig. 1) [10]. The integration of peripheral signals is not limited to the hypothalamus, but includes other brain areas such as the limbic system, the cortex, the midbrain, and the brain stem. Signals induced by the hormones of EECs in response to the volume of food, the caloric content, and the quality of food are integrated in different brain areas, which participate in appetite regulation, such as the hypothalamus (fig. 1). Some of the key neurons are located in the arcuate nucleus (ARC), which is located outside the bloodbrain barrier. Thus, the ARC is accessible by circulating hormones, e.g. ghrelin, which activates appetite-stimulating neuropeptides NPY and AgRP. The neuronal input of satiety from the periphery is mediated via the vagus nerve to the brain stem and the nucleus tractus solitarius. Gut hormones play an important role in the digestive process, regulating appetite and satiety via the gut-brain axis as reviewed in part 1 [11]. Ghrelin, PYY, GLP-1, and cholecystokinin (CCK) are released in the periphery in response to the presence or absence of nutrients in the gut and are able to act peripherally on the vagus nerve and centrally on target areas in the hypothalamus (fig. 1).

In addition, a crosstalk between the adipose tissue and the gut may also be relevant in the context of the regulation of energy homeostasis, satiety, and body weight. Leptin is released continuously from adipose tissue into the circulation and acts mainly on the hypothalamus to regulate long-term energy storage (fig. 1). In addition, exocrine-secreted gastric leptin is proposed to ensure proper food processing and food intake in the short term independent of adipose-derived leptin [12]. Thus, gastric- and adipose-derived leptin may complement one another [13].

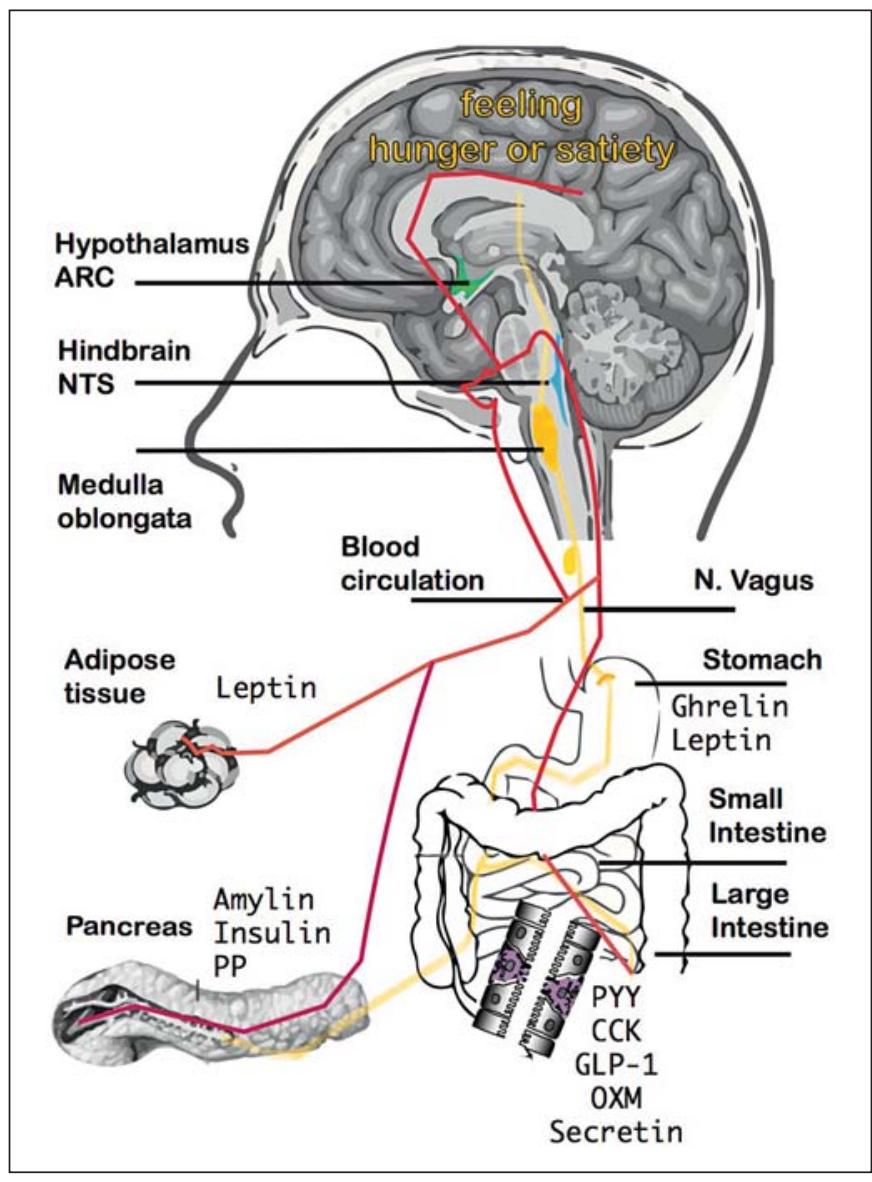

Fig. 1. Neuroendocrine circuits from the periphery to the appetite centres of the brain. Peripheral signals influence appetite centres of the brain. Therefore, EECs (violet) located along the GI tract release anorexigenic hormones such as PYY, CCK, GLP-1, OXM, or secretin via the vagus nerve (yellow) to the brainstem and nucleus tractus solitarius (NTS) (blue) or via the blood circulation (red) to the ARC in the hypothalamus (green) in order to signal short-term food inhibition, or they release orexigenic ghrelin that acts only via the ARC and activates appetite-stimulating neuropeptides. In addition, other peripheral regulators such as the adipose tissue-derived leptin and the pancreas-derived amylin, insulin, and pancreatic peptide (PP) inhibit food intake and may interact with the gut-brain axis. Adapted and modified from Roth and Reinehr [9].

\section{GI Hormones during Weight Changes}

Lifestyle intervention is recommended as first-line therapy for adult as well as for childhood obesity and comprises diet, exercise, and behavioural interventions $[14,15]$. Programmes for obese children, which target the parents and home settings, are more effective for weight loss or maintenance than programmes which only focus
Posovszky/Wabitsch 
on the behaviour of the children $[15,16]$. It is well known that a hypocaloric diet leads to promising weight loss during the first months.

So far, the reported changes of GI hormones in connection with weight loss during lifestyle intervention are inconclusive. In adults, weight loss leads to a significant reduction in circulating levels of leptin, PYY, CCK, and insulin [17]. This is accompanied by a sustained increase in ghrelin and gastric inhibitory peptide (GIP) levels in the circulation [17]. Obesity in children is associated with reduced serum levels of ghrelin and PYY, while GLP-1 levels are unchanged compared to lean children [18-20]. Some data in children have shown that weight loss leads to an increase in PYY serum levels, while ghrelin levels remain unchanged or increase and GLP-1 levels decrease [18-21]. The initial alterations of gut hormones in obese children seem, therefore, to be reversible after weight loss [9]. One study, however, showed no changes in fasting or postprandial GLP-1 and PYY levels in obese children after weight reduction [22].

After weight loss during lifestyle intervention programmes, the majority of individuals will regain weight within the following months [1]. The high rate of relapses may be at least partly explained by the long-lasting counter-regulatory effect of several appetite-regulating hormones produced by the EECs. In fact, a recent study in adults has demonstrated that changes in circulating GI hormones induced by weight loss persist even after 1 year [17]. Thus, they may contribute to the observed propensity to regain weight, and long-term strategies to counteract these changes may be needed to prevent obesity relapse.

\section{The Role of EECs in Bariatric Surgery}

Bariatric surgery is the only successful treatment option leading to long-term weight loss with clinical relevance resulting in an improvement of obesity-associated comorbidities including type 2 diabetes. The most frequently applied method is the Roux-en-Y gastric bypass (RYGB) operation.

Recent data on patients after bariatric surgery show that unlike the effects of lifestyle changes and hypocaloric diets, bariatric surgery results in meaningful increases in circulating levels of PYY and GLP-1 and a decrease in ghrelin level [23]. GI bypass operations create a connection of two separated segments of the gut, thereby bypassing the entire duodenum and part of the jejunum, and resulting in an altered flow of nutrients

Gastrointestinal Satiety Signalling and Obesity reaching the distal part of the small intestine more rapidly than usual. According to the 'lower intestinal hypothesis' [24] (also known as 'distal' or 'foregut hypothesis'), the rapid delivery of nutrients to the lower intestine and the colon leads to an excessive stimulation of $\mathrm{L}$ cells resulting in an altered secretion profile of GI hormones. In addition, bile acids which reach the distal intestine and the colon in an undiluted state via the biliopancreatic loop lead to a stimulation of $\mathrm{L}$ cells by the farnesoid receptor X [25]. Indeed, most data support this theory, showing increased levels of GLP-1, PYY, and oxyntomodulin (OXM) after RYGB operation [26, 27]. However, in one study, a decrease in GLP-1 levels was observed after bariatric surgery of morbidly obese adults [28].

The secretion of GLP-1 and PYY is directly associated with the caloric content of the chyme reaching the distal intestine. There is a positive correlation between the postprandial PYY and GLP-1 levels and the amount of weight loss after a RYGB operation [29]. Along with an elevated GLP-1 level, a decrease in dipeptidyl peptidase-4 (DPP-4), which rapidly degrades GLP-1, was found in patients after bypass surgery [30]. Interestingly, experimental inhibition of PYY and GLP-1 secretion with the somatostatin analogue octreotide resulted in an increased appetite and weight gain after RYGB operation [29]. Thus, an increase in PYY and GLP-1 after RYGB operation may account for the beneficial effects on satiety.

Besides the effects of these satiety hormones on appetite and food intake after bariatric surgery, a second mechanism leads to the enormous benefits of bariatric surgery. Gastric bypass operations lead to successful diabetes resolution in up to $80 \%$ of patients lasting up to 14 years postoperatively [31]. It is now clear that rapid resolution of type 2 diabetes is achieved by bypass surgery before substantial weight loss is observed. This is partly due to an increase in GLP-1 secretion. GLP-1 is able to improve glucose homeostasis by stimulating insulin secretion and GIP secretion and by suppressing glucagon secretion [32].

\section{Is There an Alternative to Bariatric Surgery?}

Pharmacological treatment strategies imitating the hormonal and malabsorptive changes induced by bypass surgery could probably be as effective as bypass surgery. For example, fat malabsorption can be induced by gastric and pancreatic lipase inhibitors such as Orlistat or Cetili- 
stat. Orlistat, which was approved in 1998 by the Food and Drug Administration (FDA) for the treatment of obesity, accelerates gastric emptying and reduces CCK, GLP-1, PYY, and GIP release from EECs after a mixed meal [33]. However, only one third of patients treated with Orlistat achieved a weight loss greater than 5\% after 12 months of therapy [34].

GLP-1 agonists have been investigated as therapeutic tools as they exhibit an anti-diabetic function [35]. GLP-1 agonists such as exenatide or liraglutide improved glycaemic control and led to a reduction in body weight in obese humans [36, 37]. Moreover, combining gut hormones with almost the same function might induce complementary action. For example, the combination of GLP-1 1 -36 and $\mathrm{PYY}_{3-36}$ has an additive anorectic effect in humans [38]. The rapid degradation of GLP-1 by DPP-4 in vivo was solved by the acetylated analogue liraglutide with a considerable extended half-life up to 11-15 h. A recently discovered peptide derived from an intermixed sequence of GLP-1 and GIP showed an anti-hyperglycaemic and insulinotropic effect in synergism with a loss of fat mass in obese rodents [39].

Taken together, in addition to lifestyle interventions, future multifactorial long-term medical treatment approaches for obesity might include gastric and pancreatic lipase inhibitors as well as dietary or pharmacological regulators of gut hormones, e.g. simulating GLP-1, GIP, or PYY releases.

\section{Appetite Regulation by Targeting EEC Nutrient Receptors}

New anti-obesity drugs often fail to achieve a significant weight loss greater than $5 \%$ and are not superior to educational programs. In addition, they lead to side effects, most commonly nausea, cardiovascular events, and psychological side effects [40]. Moreover, effective antiobesity drugs working on the central nervous system have been withdrawn from the market due to severe side effects, e.g. sibutramine or rimonabant [41]. These drugs mainly affected the central nervous system. Thus, we need to consider the potential of EECs and their hormones to regulate food intake, digestion, and thereby body weight without the adverse effects caused by systemic administration or by affecting primarily a central target. Triggering the enteroendocrine network by administration of nutritive factors or drug compounds might increase the efficacy of weight loss and simulate the physiologic signals of satiation and appetite control.
Nutritive stimulation of taste receptors of enteroendocrine $\mathrm{L}$ cells in the distal small intestine and colon in order to induce endogenous gut hormone release should be considered. Indeed, in vitro stimulation of sweet taste receptors in immortalized and primary L-cell cultures induces hormone release, e.g. PYY, GLP-1, and OXM $[42,43]$. These hormones have a profound effect on satiety. The orphan G-protein-coupled class 1 receptor GPR119 is expressed in pancreatic tissue and the L-cellderived GLUTag cell line. Endovanilloid compounds are potent natural agonists of GPR119 (fig. 2). Orally applied GPR119 agonists induce the release of incretin hormones GLP-1 or GIP and are potent anti-diabetic drugs [4]. In addition, selective small-molecule GPR119 agonists inhibit gastric emptying and suppress food intake, thereby leading to reduced weight gain and fat pad masses in rodent models of obesity (fig. 2) [4]. Thus, specifically targeting nutrient receptors via oral or rectal administration is promising and needs further investigation. The endogenous release of gut hormones may be an effective long-term treatment strategy not only in obesity but also in type 2 diabetes [4]. Certainly, these drugs need to be studied intensively regarding potential side effects.

\section{Nutritional Factors Influence the Plasticity of EECs}

The very high turnover of EECs due to their short life span of around 4-6 days allows an extensive plasticity in contrast to other non-diffuse endocrine organs [44]. EECs revolve continuously from pluripotent intestinal stem cells from the villous crypts [11]. Differentiation is controlled by basic helix-loop-helix (bHLH) transcription factors. Interestingly, high-fat feeding reduces the expression of bHLH transcription factors and thereby the number of EECs [45]. In addition, intestinal gut hormone levels show a subsequent decrease [45], demonstrating that high-fat feeding influences EEC differentiation and may thereby influence satiety and the development of obesity (fig. 3). Indeed, a high-fat diet suppresses lipidinduced CCK satiation signalling in obese-prone rats [46]. Furthermore, high-energy/high-fat feeding results in reduced GLP-1 serum levels in these rats [47]. Other studies demonstrated that non-digestible carbohydrates promote L-cell differentiation in the proximal colon via upregulation of bHLH transcription factors neurogenin 3 and NeuroD resulting in higher GLP-1 production [5]. Dietary fibres such as oligofructose have been shown to reduce food intake (fig. 2) [48]. Finally, changing the 
quality of nutritional intake is accompanied by a modulation of the gut microbiota, which in turn probably affects EECs.

\section{The Impact of Microbiota on EECs and Food Intake}

The microbiome influences gut homeostasis. Bacterial metabolic products or bacterial factors are able to directly interact with the intestinal epithelium. Furthermore, microbes can activate EECs to secrete, for example, serotonin and thereby stimulate enteric nerves and regulate GI motility and secretion. There is evidence that the EEC metabolism is controlled by the microbiome. Among pathological conditions, the microbiome plays a role in the development of diabetes and obesity by triggering low-grade inflammation, gut barrier dysfunction, and metabolic endotoxaemia [8]. Gut microbiota-derived lipopolysaccharides (LPS) have been identified as a key factor in the early development of low-grade inflammation and metabolic diseases $[8,49]$. In addition, fat feeding and a high-fat diet induce elevated plasma LPS levels, the so-called metabolic endotoxaemia [49] (fig. 3). Identifying the underlying mechanism of low-grade inflammation and metabolic endotoxaemia is therefore important.

Indeed, a significant change in the microbiome of obese individuals is present with lower anti-inflammatory Bacteroides proportions compared to lean individuals [50]. Even a microbiome with higher levels of Staphylococcus aureus and lower levels of Bifidobacteria during childhood may predict overweight [51]. However, it is still unclear whether gut microbiota alterations are caused by the diet or by the pathology of obesity itself. Interestingly, faecal transplantation of gut microbiota from a lean healthy donor temporarily improves insulin sensitivity in patients with metabolic syndrome [52].

According to rodent models, modulation of the microbiome by using prebiotics may improve gut barrier function, metabolic endotoxaemia, and inflammation in obesity and type 2 diabetes [53]. Prebiotics are able to decrease LPS levels in the circulation and increase faecal concentrations of short-chain fatty acids (SCFAs) [54]. Fibre fermentation leads to SCFAs, which can induce the expression of proglucagon, the precursor of GLP-1 [6]. Thus, prebiotics may change food intake and GI hormone secretion and influence the microbiome (fig. 2). Indeed, prebiotics increase GLP-1 and PYY and decrease ghrelin secretion in humans $[6,7]$. In addition, the positive effects of prebiotics are associated with an increase in the num-

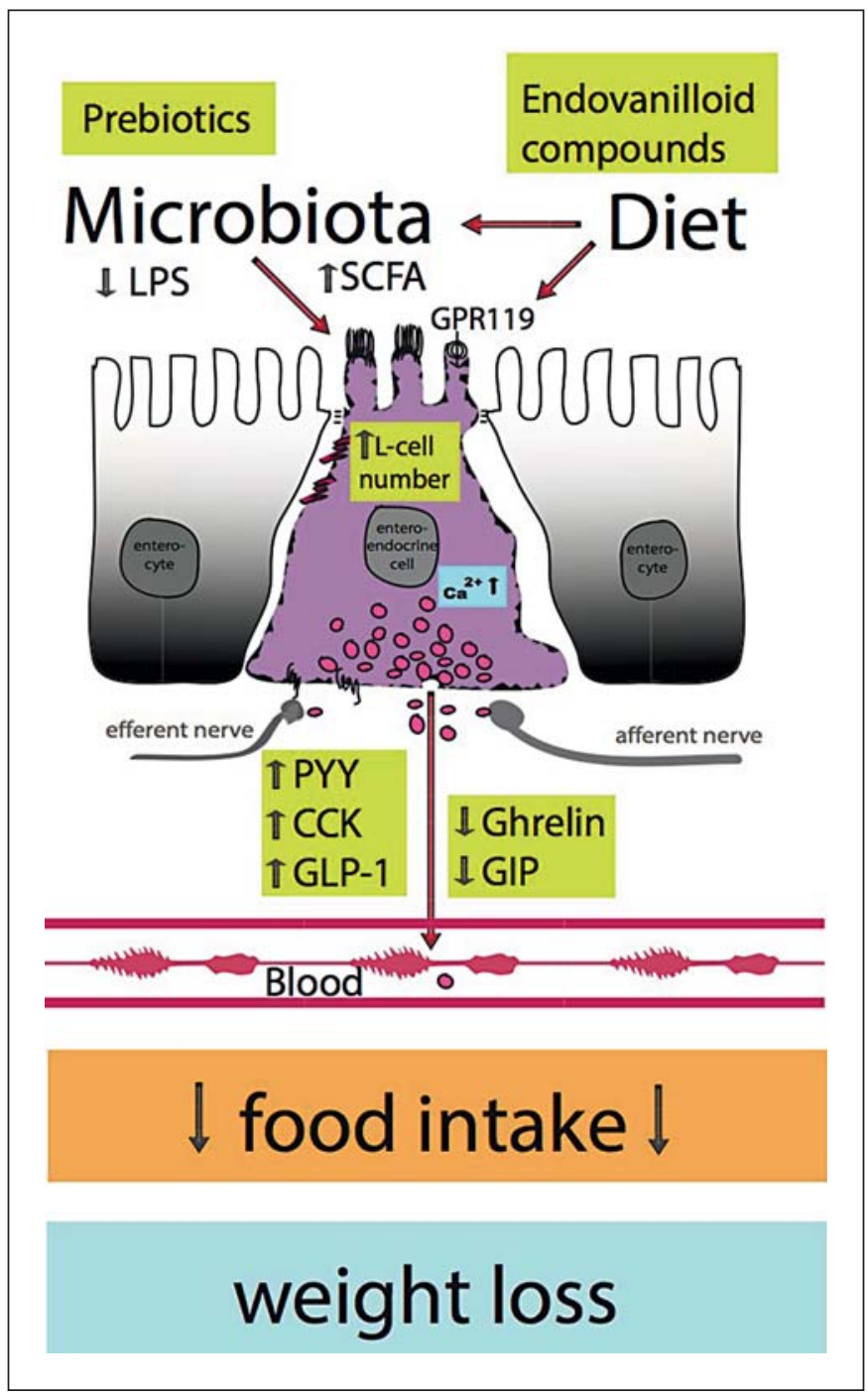

Fig. 2. Effects of prebiotics and endovanilloid compounds on EEC behaviour and food intake. EECs (violet) sense the luminal content on the apical membrane with, for example, G-proteincoupled receptors (GPRs). The release of hormone-containing secretory vesicles (pink) is controlled by the intracellular $\mathrm{Ca}^{2+}$ content (pale blue). Prebiotics, non-digestible fiber compounds such as oligofructose, induce SCFAs and increase the EEC number and thereby alter peptide release. In addition, prebiotics change the gut microbiota composition with a reduction of LPS and thereby increase the integrity of the gut barrier and prevent bacterial metabolites from crossing the barrier, entering the circulation, and promoting systemic inflammation. Similar endovanilloid compounds and GPR119 agonists induce the expression of incretin hormones and thereby suppress food intake and weight gain. 


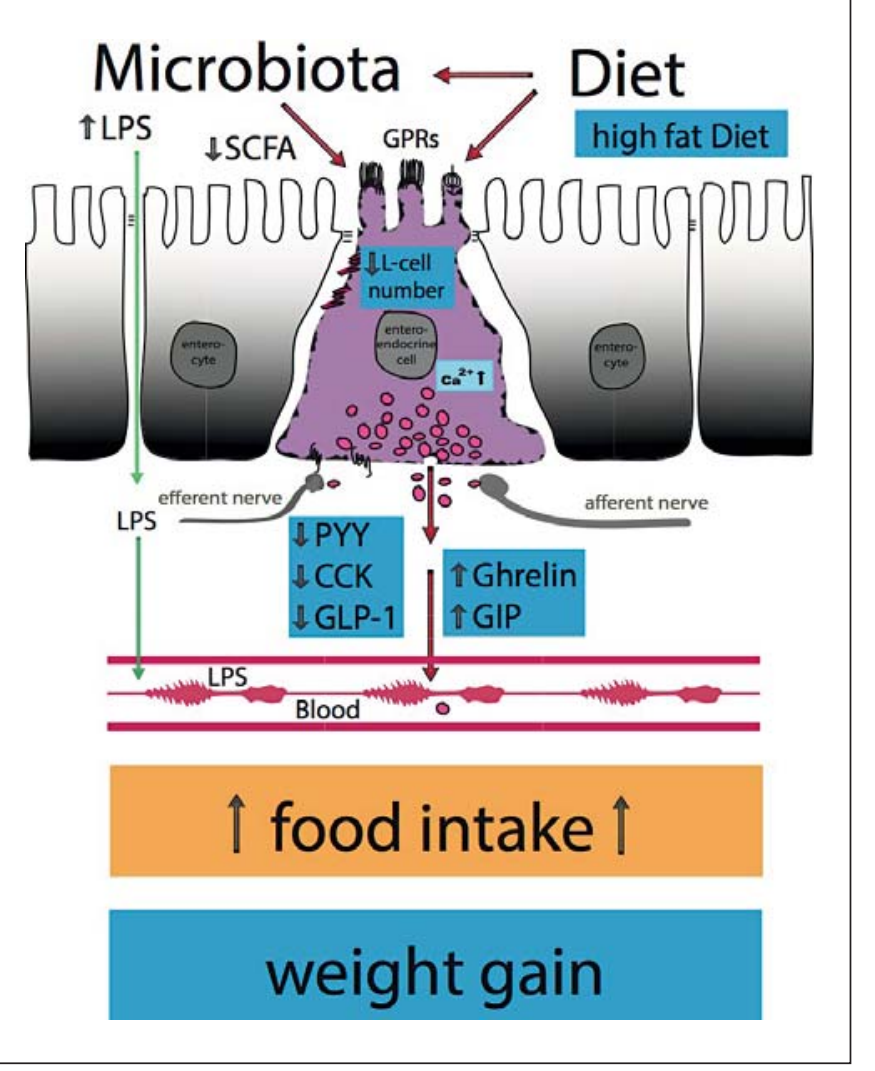

Fig. 3. Effects of high-fat diet on EEC behaviour and food intake. EECs (violet) sense the luminal content on the apical membrane with, for example, G-protein-coupled receptors (GPRs). The release of hormone-containing secretory vesicles (pink) is controlled by the intracellular $\mathrm{Ca}^{2+}$ content (pale blue). A high-fat diet alters the EEC number and peptide release, i.e. the lipid-mediated satiety signalling via CCK is reduced and thereby may promote food intake and obesity. In addition, a high-fat diet changes the gut microbiota composition and thus increases LPS together with a reduction of bacteria necessary for the integrity of the gut barrier, allowing LPS and other bacterial metabolites to cross the barrier, enter the circulation (green arrow), and promote systemic inflammation. ber of L cells in the intestine and GLP-2-mediated improvement of gut permeability $[53,55]$. This effect is dose dependent and suggests that prebiotics may have a therapeutic potential for the treatment of obesity and type 2 diabetes [8].

\section{Conclusion}

There is an enormous demand on an effective obesity treatment, but there is concern about the safety of antiobesity drugs. Medical combination therapies imitating the physiological changes observed after bypass surgery might be as effective as bariatric surgery. Unfortunately, effective anti-obesity drugs have been withdrawn from the market due to severe side effects. Thus, in addition to lifestyle intervention, targeting specifically EECs as key regulators in the peripheral control of food intake and obesity seems to be a promising strategy with less adverse events. Indeed, GI hormones from EECs play an important role in the sustained weight loss and metabolic improvements achieved by gastric bypass operations. Recent advances in our knowledge regarding the food-sensing skills of EECs and the interaction with different macronutrients or diets and the gut microbiota may lead to new therapeutic approaches, starting with dietary modifications and prebiotics as a considerable strategy to prevent and treat metabolic diseases. Investigating the EEC network as a therapeutic target in the context of body weight regulation and type 2 diabetes is promising.

\section{Disclosure Statement}

The authors declare that they have no conflicts of interest.

\section{References}

1 Casazza K, Fontaine KR, Astrup A, Birch LL, Brown AW, Bohan Brown MM, Durant N, Dutton G, Foster EM, Heymsfield SB, McIver K, Mehta T, Menachemi N, Newby PK, Pate R, Rolls BJ, Sen B, Smith DL Jr, Thomas DM, Allison DB: Myths, presumptions, and facts about obesity. N Engl J Med 2013;368:446454.

-2 Sjostrom L, Narbro K, Sjostrom CD, Karason K, Larsson B, Wedel H, Lystig T, Sullivan M, Bouchard C, Carlsson B, Bengtsson C, Dahlgren S, Gummesson A, Jacobson P, Karlsson J, Lindroos AK, Lonroth H, Naslund I, Olbers T,
Stenlof K, Torgerson J, Agren G, Carlsson LM: Effects of bariatric surgery on mortality in Swedish obese subjects. N Engl J Med 2007; 357:741-752.

-3 Le Roux CW, Aylwin SJ, Batterham RL, Borg CM, Coyle F, Prasad V, Shurey S, Ghatei MA, Patel AG, Bloom SR: Gut hormone profiles following bariatric surgery favor an anorectic state, facilitate weight loss, and improve metabolic parameters. Ann Surg 2006;243:108114.

4 Overton HA, Fyfe MC, Reynet C: GPR119, a novel $\mathrm{G}$ protein-coupled receptor target for the treatment of type 2 diabetes and obesity. $\mathrm{Br} \mathrm{J}$ Pharmacol 2008;153(suppl 1):S76-S81.

$\checkmark 5$ Cani PD, Hoste S, Guiot Y, Delzenne NM: Dietary non-digestible carbohydrates promote L-cell differentiation in the proximal colon of rats. Br J Nutr 2007;98:32-37.

-6 Cani PD, Lecourt E, Dewulf EM, Sohet FM, Pachikian BD, Naslain D, De Backer F, Neyrinck AM, Delzenne NM: Gut microbiota fermentation of prebiotics increases satietogenic and incretin gut peptide production with consequences for appetite sensation and glucose response after a meal. Am J Clin Nutr 2009;90:1236-1243. 
7 Parnell JA, Reimer RA: Prebiotic fibres dosedependently increase satiety hormones and alter Bacteroidetes and Firmicutes in lean and obese JCR:LA-cp rats. Br J Nutr 2012;107: 601-613.

8 Everard A, Cani PD: Diabetes, obesity and gut microbiota. Best Pract Res Clin Gastroenterol 2013;27:73-83.

9 Roth CL, Reinehr T: Roles of gastrointestinal and adipose tissue peptide in childhood obesity and changes after weight loss due to lifestyle intervention. Arch Pediatr Adolesc Med 2010;164:131-138.

10 Hellstrom PM: Satiety signals and obesity. Curr Opin Gastroenterol 2013;29:222-227.

11 Posovszky C, Wabitsch M: Regulation of appetite, satiation, and body weight by enteroendocrine cells. Part 1: characteristics of enteroendocrine cells and their capability of weight regulation. Horm Res Paediatr DOI: $10.1159 / 000368898$.

-12 Cammisotto PG, Levy E, Bukowiecki LJ, Bendayan M: Cross-talk between adipose and gastric leptins for the control of food intake and energy metabolism. Prog Histochem Cytochem 2010;45:143-200.

13 Cammisotto P, Bendayan M: A review on gastric leptin: the exocrine secretion of a gastric hormone. Anat Cell Biol 2012;45:1-16.

14 Moss A, Kunze D, Wabitsch M: Evidencebased therapy guideline of the German Working Group on Obesity in Childhood and Adolescence (in German). Bundesgesundhbl Gesundheitsforsch Gesundheitsschutz 2011;54: 584-590.

15 Reinehr T: Lifestyle intervention in childhood obesity: changes and challenges. Nat Rev Endocrinol 2013;9:607-614.

-16 McLean N, Griffin S, Toney K, Hardeman W: Family involvement in weight control, weight maintenance and weight-loss interventions: a systematic review of randomised trials. Int J Obes Relat Metab Disord 2003;27: 987-1005.

17 Sumithran P, Prendergast LA, Delbridge E, Purcell K, Shulkes A, Kriketos A, Proietto J: Long-term persistence of hormonal adaptations to weight loss. N Engl J Med 2011;365: 1597-1604.

18 Roth CL, Enriori PJ, Harz K, Woelfle J, Cowley MA, Reinehr T: Peptide YY is a regulator of energy homeostasis in obese children before and after weight loss. J Clin Endocrinol Metab 2005;90:6386-6391.

$\checkmark 19$ Reinehr T, Roth CL, Alexy U, Kersting M, Kiess W, Andler W: Ghrelin levels before and after reduction of overweight due to a low-fat high-carbohydrate diet in obese children and adolescents. Int J Obes (Lond) 2005;29:362368.

20 Reinehr T, de Sousa G, Roth CL: Fasting glucagon-like peptide- 1 and its relation to insulin in obese children before and after weight loss. J Pediatr Gastroenterol Nutr 2007;44: 608-612.
21 Krohn K, Boczan C, Otto B, Heldwein W, Landgraf R, Bauer CP, Koletzko B: Regulation of ghrelin is related to estimated insulin sensitivity in obese children. Int J Obes (Lond) 2006;30:1482-1487.

22 Vos RC, Pijl H, Wit JM, van Zwet EW, van der Bent C, Houdijk EC: The effect of multidisciplinary lifestyle intervention on the pre- and postprandial plasma gut peptide concentrations in children with obesity. ISRN Endocrinol 2011;2011:353756.

23 Ochner CN, Gibson C, Carnell S, Dambkowski C, Geliebter A: The neurohormonal regulation of energy intake in relation to bariatric surgery for obesity. Physiol Behav 2010;100: 549-559.

24 Cummings DE, Overduin J, Foster-Schubert KE, Carlson MJ: Role of the bypassed proximal intestine in the anti-diabetic effects of bariatric surgery. Surg Obes Relat Dis 2007;3: 109-115.

25 Makishima M, Okamoto AY, Repa JJ, Tu H, Learned RM, Luk A, Hull MV, Lustig KD, Mangelsdorf DJ, Shan B: Identification of a nuclear receptor for bile acids. Science 1999; 284:1362-1365

26 Laferrere B, Swerdlow N, Bawa B, Arias S, Bose M, Olivan B, Teixeira J, McGinty J, Rother KI: Rise of oxyntomodulin in response to oral glucose after gastric bypass surgery in patients with type 2 diabetes. J Clin Endocrinol Metab 2010;95:4072-4076.

27 Hage MP, Safadi B, Salti I, Nasrallah M: Role of gut-related peptides and other hormones in the amelioration of type 2 diabetes after Roux-en-Y gastric bypass surgery. ISRN Endocrinol 2012;2012:504756.

28 Reinehr T, Roth CL, Schernthaner GH, Kopp HP, Kriwanek S, Schernthaner G: Peptide YY and glucagon-like peptide-1 in morbidly obese patients before and after surgically induced weight loss. Obes Surg 2007;17:15711577.

29 Le Roux CW, Welbourn R, Werling M, Osborne A, Kokkinos A, Laurenius A, Lonroth H, Fandriks L, Ghatei MA, Bloom SR, Olbers T: Gut hormones as mediators of appetite and weight loss after Roux-en-Y gastric bypass. Ann Surg 2007;246:780-785.

30 Alam ML, Van der Schueren BJ, Ahren B, Wang GC, Swerdlow NJ, Arias S, Bose M, Gorroochurn P, Teixeira J, McGinty J, Laferrere B: Gastric bypass surgery, but not caloric restriction, decreases dipeptidyl peptidase- 4 activity in obese patients with type 2 diabetes. Diabetes Obes Metab 2011;13:378-381.

31 Ashrafian H, Athanasiou T, Li JV, Bueter M, Ahmed K, Nagpal K, Holmes E, Darzi A, Bloom SR: Diabetes resolution and hyperinsulinaemia after metabolic Roux-en-Y gastric bypass. Obes Rev 2011;12:e257-e272.

32 Holst JJ: Enteroendocrine secretion of gut hormones in diabetes, obesity and after bariatric surgery. Curr Opin Pharmacol 2013; 13: 983-988.
33 Enc FY, Ones T, Akin HL, Dede F, Turoglu HT, Ulfer G, Bekiroglu N, Haklar G, Rehfeld JF, Holst JJ, Ulusoy NB, Imeryuz N: Orlistat accelerates gastric emptying and attenuates GIP release in healthy subjects. Am J Physiol Gastrointest Liver Physiol 2009;296:G482G489.

34 Rucker D, Padwal R, Li SK, Curioni C, Lau DC: Long term pharmacotherapy for obesity and overweight: updated meta-analysis. BMJ 2007;335:1194-1199.

35 Drucker DJ: Incretin action in the pancreas: potential promise, possible perils, and pathological pitfalls. Diabetes 2013;62:3316-3323.

- 36 Buse JB, Drucker DJ, Taylor KL, Kim T, Walsh B, Hu H, Wilhelm K, Trautmann M, Shen LZ, Porter LE: DURATION-1: exenatide once weekly produces sustained glycemic control and weight loss over 52 weeks. Diabetes Care 2010;33:1255-1261.

- 37 Van Can J, Sloth B, Jensen CB, Flint A, Blaak EE, Saris WH: Effects of the once-daily GLP-1 analog liraglutide on gastric emptying, glycemic parameters, appetite, and energy metabolism in obese, non-diabetic adults. Int J Obes (Lond) 2014;38:784-793.

38 Neary NM, Small CJ, Druce MR, Park AJ, Ellis SM, Semjonous NM, Dakin CL, Filipsson K, Wang F, Kent AS, Frost GS, Ghatei MA, Bloom SR: Peptide YY3-36 and glucagon-like peptide-17-36 inhibit food intake additively. Endocrinology 2005; 146:5120-5127.

39 Finan B, Ma T, Ottaway N, Muller TD, Habegger KM, Heppner KM, Kirchner H, Holland J, Hembree J, Raver C, Lockie SH, Smiley DL, Gelfanov V, Yang B, Hofmann S, Bruemmer D, Drucker DJ, Pfluger PT, PerezTilve D, Gidda J, Vignati L, Zhang L, Hauptman JB, Lau M, Brecheisen M, Uhles S, Riboulet W, Hainaut E, Sebokova E, CondeKnape K, Konkar A, DiMarchi RD, Tschop $\mathrm{MH}$ : Unimolecular dual incretins maximize metabolic benefits in rodents, monkeys, and humans. Sci Transl Med 2013;5:209ra151.

40 McGavigan AK, Murphy KG: Gut hormones: the future of obesity treatment? Br J Clin Pharmacol 2012;74:911-919.

-41 Cheung BM, Cheung TT, Samaranayake NR Safety of antiobesity drugs. Ther Adv Drug Saf 2013;4:171-181.

42 Jang HJ, Kokrashvili Z, Theodorakis MJ, Carlson OD, Kim BJ, Zhou J, Kim HH, Xu X, Chan SL, Juhaszova M, Bernier M, Mosinger B, Margolskee RF, Egan JM: Gut-expressed gustducin and taste receptors regulate secretion of glucagon-like peptide-1. Proc Natl Acad Sci USA 2007;104:15069-15074.

43 Steinert RE, Gerspach AC, Gutmann H, Asarian L, Drewe J, Beglinger C: The functional involvement of gut-expressed sweet taste receptors in glucose-stimulated secretion of glucagon-like peptide-1 (GLP-1) and peptide YY (PYY). Clin Nutr 2011;30:524-532.

44 Schonhoff SE, Giel-Moloney M, Leiter AB Development and differentiation of gut endocrine cells. Endocrinology 2004;145:26392644.
Gastrointestinal Satiety Signalling and Obesity
Horm Res Paediatr 2015;83:11-18 DOI: $10.1159 / 000369555$ 
45 Sakar Y, Duca FA, Langelier B, Devime F, Blottiere H, Delorme C, Renault P, Covasa M: Impact of high-fat feeding on basic helixloop-helix transcription factors controlling enteroendocrine cell differentiation. Int $\mathrm{J}$ Obes (Lond) 2014;38:1440-1448.

46 Duca FA, Zhong L, Covasa M: Reduced CCK signaling in obese-prone rats fed a high fat diet. Horm Behav 2013;64:812-817.

47 Duca FA, Sakar Y, Covasa M: Combination of obesity and high-fat feeding diminishes sensitivity to GLP-1R agonist exendin-4. Diabetes 2013;62:2410-2415.

-48 Cani PD, Neyrinck AM, Maton N, Delzenne NM: Oligofructose promotes satiety in rats fed a high-fat diet: involvement of glucagonlike peptide-1. Obes Res 2005;13:1000-1007.

- 49 Cani PD, Amar J, Iglesias MA, Poggi M, Knauf C, Bastelica D, Neyrinck AM, Fava F, Tuohy KM, Chabo C, Waget A, Delmee E, Cousin B, Sulpice T, Chamontin B, Ferrieres J, Tanti JF, Gibson GR, Casteilla L, Delzenne NM, Alessi MC, Burcelin R: Metabolic endo- toxemia initiates obesity and insulin resistance. Diabetes 2007;56:1761-1772.

50 Turnbaugh PJ, Ley RE, Mahowald MA, Magrini V, Mardis ER, Gordon JI: An obesityassociated gut microbiome with increased capacity for energy harvest. Nature 2006;444: 1027-1031.

51 Kalliomaki M, Collado MC, Salminen S, Isolauri E: Early differences in fecal microbiota composition in children may predict overweight. Am J Clin Nutr 2008;87:534-538.

52 Vrieze A, Van Nood E, Holleman F, Salojarvi J, Kootte RS, Bartelsman JF, Dallinga-Thie GM, Ackermans MT, Serlie MJ, Oozeer R, Derrien M, Druesne A, Van Hylckama Vlieg JE, Bloks VW, Groen AK, Heilig HG, Zoetendal EG, Stroes ES, de Vos WM, Hoekstra JB, Nieuwdorp M: Transfer of intestinal microbiota from lean donors increases insulin sensitivity in individuals with metabolic syndrome. Gastroenterology 2012;143:913-916.e917.

53 Cani PD, Possemiers S, Van de Wiele T, Guiot Y, Everard A, Rottier O, Geurts L, Naslain
D, Neyrinck A, Lambert DM, Muccioli GG, Delzenne NM: Changes in gut microbiota control inflammation in obese mice through a mechanism involving GLP-2-driven improvement of gut permeability. Gut 2009;58: 1091-1103.

54 Lecerf JM, Depeint F, Clerc E, Dugenet Y, Niamba CN, Rhazi L, Cayzeele A, Abdelnour G, Jaruga A, Younes H, Jacobs H, Lambrey G, Abdelnour AM, Pouillart PR: Xylo-oligosaccharide (XOS) in combination with inulin modulates both the intestinal environment and immune status in healthy subjects, while XOS alone only shows prebiotic properties. Br J Nutr 108:1847-1858.

55 Everard A, Lazarevic V, Derrien M, Girard M, Muccioli GG, Neyrinck AM, Possemiers S, Van Holle A, Francois P, de Vos WM, Delzenne NM, Schrenzel J, Cani PD: Responses of gut microbiota and glucose and lipid metabolism to prebiotics in genetic obese and diet-induced leptin-resistant mice. Diabetes 2011;60:2775-2786. 